\title{
Nocardioides daphniae sp. nov., isolated from Daphnia cucullata (Crustacea: Cladocera)
}

\author{
Correspondence \\ Erika M. Tóth \\ totherika@ludens.elte.hu
}

\author{
Erika M. Tóth, ${ }^{1}$ Zsuzsa Kéki, ${ }^{1}$ Zalán G. Homonnay, ${ }^{1}$ Andrea K. Borsodi, ${ }^{1}$ \\ Károly Márialigeti ${ }^{1}$ and Peter Schumann ${ }^{2}$
}
${ }^{1}$ Eötvös Loránd University, Faculty of Science, Department of Microbiology, Pázmány Péter sétány 1/c, $\mathrm{H}-1117$ Budapest, Hungary
${ }^{2}$ DSMZ-German Collection of Microorganisms and Cell Cultures, Inhoffenstraße 7B, D-38124 Braunschweig, Germany

\begin{abstract}
A Gram-positive, rod-shaped or coccoid, yellow-pigmented bacterial strain, $\mathrm{D} 287^{\top}$, was isolated from the water flea Daphnia cucullata (Crustacea: Cladocera) collected from Lake Balaton in Hungary. Phylogenetic analysis on the basis of $16 \mathrm{~S}$ rRNA gene sequence comparisons revealed that the strain represented a distinct lineage within the cluster of the genera Nocardioides and Marmoricola. The following characteristics were consistent with the affiliation of strain $\mathrm{D} 287^{\top}$ to the genus Nocardioides: peptidoglycan based on LL-2,6-diaminopimelic acid, MK-8 $\left(\mathrm{H}_{4}\right)$ as the major menaquinone, iso- $\mathrm{C}_{16: 0}$ as the predominant cellular fatty acid, the presence of phosphatidylglycerol and diphosphatidylglycerol and a DNA G+C content of $69.9 \mathrm{~mol} \%$. Owing to characteristic differences in physiological traits and levels of 16S rRNA gene sequence similarity to its phylogenetically closest neighbours that were below $97 \%$, strain $D 287^{\top}$ is considered to represent a novel species of the genus Nocardioides, for which the name Nocardioides daphniae sp. nov. is proposed. The type strain is D287 ${ }^{\top}$ (=DSM $18664^{\top}=\mathrm{CCM}$ $\left.7403^{\top}\right)$.
\end{abstract}

Crustacean species, among them Daphnia cucullata (Crustacea: Cladocera) (G.-Tóth, 2000), are the most frequent members of the zooplankton of Lake Balaton (Hungary) and play a key role in the food web and energy circulation of the lake as a result of their filtration-type feeding. A detailed bacteriological investigation was performed with this crustacean species based on the isolation and identification of bacteria associated with it (Homonnay et al., 2006). Among the organisms isolated, an actinobacterium (designated strain $\mathrm{D} 287^{\mathrm{T}}$ ) was detected that could be affiliated to the genus Nocardioides on the basis of morphological, physiological, chemotaxonomic and phylogenetic studies. Species of the genus Nocardioides have hitherto been isolated from soils, sands or sediments as Nocardioides albus (Prauser, 1976), N. luteus (Prauser, 1984), N. simplex (O'Donnell et al., 1982), N. jensenii (Collins et al., 1989), N. insulae (Yoon et al., 2007), N. dubius (Yoon et al., 2005c), N. alkalitolerans (Yoon et al., 2005a), N. kribbensis (Yoon et al., 2005b), N. kongjuensis (Yoon et al., 2006b), N. lentus (Yoon et al., 2006a), N. furvisabuli (Lee, 2007), N. ganghwensis (Yi \& Chun, 2004a) and N. aestuarii (Yi \& Chun, 2004b), aquatic habitats as $N$. aquiterrae (Yoon et al., 2004), N. aquaticus (Lawson et al., 2000) and N. marinus (Choi et al., 2007), meadow herbage

The GenBank/EMBL/DDBJ accession number for the 16S rRNA gene sequence of strain $D 287^{\top}$ is $A M 398438$. as N. plantarum (Collins et al., 1994), as well as from polluted environments as $N$. oleivorans (Schippers et al., 2005), N. nitrophenolicus (Yoon et al., 1999), N. pyridinolyticus (Yoon et al., 1997) and N. aromaticivorans (Kubota et al., 2005). However, an association of members of the genus Nocardioides with other organisms as described herein for strain $\mathrm{D} 287^{\mathrm{T}}$ has not previously been reported. The aim of the present work was to determine the taxonomic position of strain $\mathrm{D} 287^{\mathrm{T}}$ and to describe the novel strain by means of a polyphasic approach.

Strain D287 ${ }^{\mathrm{T}}$ was isolated in August 2004 from a wholebody homogenate sample of Daphnia cucullata (Crustacea: Cladocera) collected from Lake Balaton at Tihany $\left(46^{\circ} 55^{\prime}\right.$ $20^{\prime \prime} \mathrm{N} 17^{\circ} 55^{\prime} 39^{\prime \prime} \mathrm{E}$ ), Hungary: 30 adult individuals of $D$. cucullata were selected under a stereomicroscope (Leica), washed five times with $5 \mathrm{ml}$ sterile water from the lake, homogenized with a sterile glass mortar and used as composite sample. Bacterial strain $\mathrm{D} 287^{\mathrm{T}}$ was isolated and later maintained on King B agar medium (King et al., 1954).

Colony morphology was studied on King B agar medium by direct and stereomicroscopic observations of single colonies. Cell morphology and motility were studied by native preparations and by Gram staining according to Claus (1992).

Growth under anaerobic conditions was examined by using slant agar cultures on King B medium incubated in an 
anaerobic chamber (Forma Scientific). Oxidase activity was tested according to the method of Tarrand \& Gröschel (1982). Catalase production and the Voges-Proskauer reaction were investigated by using the methods of Cowan \& Steel (1974). Acid production from glucose was studied by the $\mathrm{O} / \mathrm{F}$ test according to Hugh \& Leifson (1953). Growth at different temperatures $\left(4,28,38,45{ }^{\circ} \mathrm{C}\right)$, $\mathrm{NaCl}$ concentration $(0,2.5,5,10 \%, \mathrm{w} / \mathrm{v})$ and $\mathrm{pH}(\mathrm{pH} 4-12$ in steps of $0.5 \mathrm{pH}$ units) were determined by using King $\mathrm{B}$ agar or broth. Urease activity, nitrate reduction, starch hydrolysis, indole production from tryptophan, caseinase, gelatinase and phosphatase activities, hydrolysis of Tween 80 and $\mathrm{H}_{2} \mathrm{~S}$ production from cysteine were studied according to the methods of Smibert \& Krieg (1994). Haemolysin production was tested on ox-blood agar plates (Elek \& Levy, 1954). Chitinase activity was studied according to a modified version of the method of Holding \& Collee (1971). Other enzyme activities were tested by using the API ZYM system (bioMérieux). Utilization of 95 different carbon sources as sole source of carbon was studied on Biolog GP2 microplates by using an ELISA reader (SUNRISE Remote; Tecan). System 3.5 was used to evaluate the results according to the manufacturer's instructions. For comparison, Biolog test results were evaluated with $N$. alkalitolerans DSM $16699^{\mathrm{T}}$, N. dubius DSM $19084^{\mathrm{T}}$ and N. jensenii DSM $20641^{\mathrm{T}}$.

The cell-wall diamino acid of strain $\mathrm{D} 287^{\mathrm{T}}$ was determined from whole-cell hydrolysates as described by Hasegawa et al. (1983). Isoprenoid quinones were extracted from cells cultivated in liquid Rich medium (Yamada \& Komagata, 1972) according to the method of Collins et al. (1977) and the profile was analysed by HPLC (HP 9001; Hewlett Packard) (Groth et al., 1997). Cellular fatty acids were extracted from cells cultivated on trypticase soy agar (Difco) at $28{ }^{\circ} \mathrm{C}$ according to Stead et al. (1992) and were analysed by GC (Groth et al., 1996). Polar lipids were determined according to the method described by Minnikin et al. (1979). The DNA base composition was determined after disruption of bacterial cells by using a French press. After purification on hydroxyapatite following the procedure of Cashion et al. (1977), the DNA was degraded to nucleosides by using P1 nuclease and bovine intestinal mucosa alkaline phosphatase as described by Mesbah et al. (1989). The nucleosides were separated by reversed-phase HPLC (HP 9001) according to Tamaoka \& Komagata (1984). The $\mathrm{G}+\mathrm{C}$ content of the DNA was calculated from the ratio of deoxyguanosine to thymidine.

Extraction of genomic DNA and PCR-mediated amplification of the $16 \mathrm{~S}$ rRNA gene of strain $\mathrm{D} 287^{\mathrm{T}}$ were carried out by using the methods of Rainey et al. (1996). The PCR product was purified by using a Prep-A-Gene kit (BioRad). Cycle sequencing was performed with the Big Dye Terminator Cycle Sequencing kit (Applied Biosystems) according to the manufacturer's protocol, and sequence analysis was performed in an Applied Biosystems model 310 Genetic Analyzer.
A BLAST (Altschul et al., 1997) and GenBank database search (http://www.ncbi.nlm.nih.gov/) for 16S rRNA gene sequences similar to that of strain $\mathrm{D} 287^{\mathrm{T}}$ was performed. Pairwise similarity values to the phylogenetically closest type strains of recognized members of the genus Nocardioides were calculated by using the SimTable analysis of the EzTaxon server (http://www.eztaxon.org). The 16S rRNA gene sequence of strain $\mathrm{D} 287^{\mathrm{T}}$ was manually aligned by using the BioEdit program (Hall, 1999) against sequences available from EMBL. Evolutionary distances were calculated according to the Kimura two-parameter method (Kimura, 1980) and a phylogenetic dendrogram was constructed by using the neighbour-joining method (Saitou \& Nei, 1987) within the CLUSTAL_X software package (Thompson et al., 1997). Bootstrap analysis was based on 1000 resamplings (Felsenstein, 1985).

Morphological, cultural and physiological characteristics of strain $\mathrm{D} 287^{\mathrm{T}}$ are given in the species description below. Phenotypic characteristics that differentiate strain D287 from its closest phylogenetic neighbours are given in Table 1.

The 16S rRNA gene sequence of strain $\mathrm{D} 287^{\mathrm{T}}$ comprised 1333 nt. The phylogenetic tree based on the neighbourjoining algorithm showed that strain $\mathrm{D} 287^{\mathrm{T}}$ represents a distinct lineage within the cluster formed by members of the genera Nocardioides and Marmoricola (Fig. 1). In addition, the BioEdit program was used for a maximum-likelihood analysis (Felsenstein, 1981), which resulted in almost the same clustering for closely related species as in the neighbourjoining tree (data not shown). Strain $\mathrm{D} 287^{\mathrm{T}}$ showed highest $16 \mathrm{~S}$ rRNA gene sequence similarity to the type strains of $N$. dubius (96.6\%), N. jensenii (96.2\%), N. pyridinolyticus (96.0\%) and N. kribbensis (95.9\%). The 16S rRNA gene sequence of strain $\mathrm{D} 287^{\mathrm{T}}$ clustered together with those of the type strains of $N$. dubius, $N$. jensenii and N. alkalitolerans in a neighbour-joining tree (Fig. 1). The phylogenetically nearest neighbours of strain $\mathrm{D} 287^{\mathrm{T}}$ were selected on the basis of pairwise similarity calculations and clustering in the phylogenetic tree, and their phenotypic characteristics as compared with the novel strain are given in Table 1.

The peptidoglycan of strain D287 ${ }^{\mathrm{T}}$ was based on LL-2,6 diaminopimelic acid. The major menaquinone was MK$8\left(\mathrm{H}_{4}\right)$. Phosphatidylglycerol, diphosphatidylglycerol and one unidentified phospholipid were found as polar lipids. The fatty acid profile (i.e. fatty acids representing $>1 \%$ of the total) of strain $\mathrm{D} 287^{\mathrm{T}}$ consisted of the following components: iso- $\mathrm{C}_{16: 0}(42.71 \%), \mathrm{C}_{18: 1} \omega 9 c(9.88 \%), \mathrm{C}_{17: 0}$ 10 -methyl (9.67\%), iso- $\mathrm{C}_{17: 1} \omega 9 c(8.10 \%)$, iso- $\mathrm{C}_{17: 0}$ $(8.09 \%), \mathrm{C}_{17: 1} \omega 8 c(3.55 \%)$, iso- $\mathrm{C}_{16: 1}(2.63 \%)$, anteiso$\mathrm{C}_{17: 0}(2.44 \%)$, iso- $\mathrm{C}_{18: 0}(2.35 \%), \mathrm{C}_{16: 1} \omega 7 c(2.19 \%)$, iso$\mathrm{C}_{14: 0}(1.72 \%)$, iso- $\mathrm{C}_{15: 0}(1.64 \%)$ and $\mathrm{C}_{18: 1} \omega 7 c(1.15 \%)$. This fatty acid profile, with a high proportion of iso- and anteiso-branched chain fatty acids, clearly differentiated strain $\mathrm{D} 287^{\mathrm{T}}$ from Marmoricola aurantiacus, which has a cellular fatty acid pattern with straight-chain saturated and monounsaturated components and 10-methyl octadecanoic (tuberculostearic) acid as the only branched-chain fatty acid 
Table 1. Differential phenotypic characteristics of strain $\mathrm{D} 287^{\top}$ and related Nocardioides species

Taxa: 1, strain D287 ${ }^{\mathrm{T}}$; 2, N. alkalitolerans; 3, N. dubius; 4, N. jensenii. Data for reference taxa are from Yoon et al. (2005a, c), Yi \& Chun (2004a), Suzuki \& Komagata (1983) and Collins et al. (1989). All carbon source utilization results are from the present study. +, Positive; -, negative; ND, not determined; $\mathrm{w}$, weakly positive; $\mathrm{v}$, variable; data in parentheses are for the type strain.

\begin{tabular}{|c|c|c|c|c|}
\hline Characteristic & 1 & 2 & 3 & 4 \\
\hline Cell size $(\mu \mathrm{m})$ & $0.8-1.0 \times 1.2-2.2$ & $0.8-1.0 \times 1.5-2.0$ & $0.8-1.0 \times 1.5-2.5$ & $0.6-0.8 \times 3.0-7.0$ \\
\hline Motility & - & - & + & - \\
\hline Colony colour & Yellowish & Milky white & Yellowish white & Yellowish white \\
\hline Optimal temperature for growth $\left({ }^{\circ} \mathrm{C}\right)$ & $28-38$ & $25-30$ & 30 & ND \\
\hline Optimal $\mathrm{pH}$ for growth & $7.5-8.5$ & $7.0-9.0$ & $7.0-8.0$ & ND \\
\hline Nitrate reduction & $(+)$ & + & $(-)$ & + \\
\hline \multicolumn{5}{|l|}{ Hydrolysis of: } \\
\hline Aesculin & $(+)$ & - & $(+)$ & - \\
\hline Casein & $(\mathrm{w})$ & + & $\mathrm{ND}$ & + \\
\hline Gelatin & $(+)$ & $\mathrm{v}(+)$ & $(+)$ & + \\
\hline Tween 80 & $(+)$ & + & $(-)$ & + \\
\hline Urea & $(-)$ & - & $(-)$ & + \\
\hline \multicolumn{5}{|l|}{ Utilization of: } \\
\hline D-Cellobiose & $(-)$ & $(+)$ & $(-)$ & $(-)$ \\
\hline D-Fructose & $(+)$ & $(+)$ & $(-)$ & $(-)$ \\
\hline D-Glucose & $(+)$ & $(+)$ & $(-)$ & $(-)$ \\
\hline Maltose & $(-)$ & $(-)$ & $(+)$ & $(-)$ \\
\hline D-Mannose & $(+)$ & $(+)$ & $(-)$ & $(-)$ \\
\hline D-Ribose & $(+)$ & $(+)$ & $(-)$ & $(-)$ \\
\hline Sucrose & $(-)$ & $(+)$ & $(-)$ & $(-)$ \\
\hline Trehalose & $(+)$ & $(+)$ & $(-)$ & $(-)$ \\
\hline Tween 40 & $(-)$ & $(+)$ & $(+)$ & $(+)$ \\
\hline Mannan & $(-)$ & $(+)$ & $(-)$ & $(-)$ \\
\hline Tween 80 & $(-)$ & $(-)$ & $(+)$ & $(+)$ \\
\hline Maltotriose & $(-)$ & $(+)$ & $(+)$ & $(-)$ \\
\hline 3-Methyl glucose & $(-)$ & $(+)$ & $(-)$ & $(-)$ \\
\hline Palatinose & $(+)$ & $(+)$ & $(-)$ & $(-)$ \\
\hline D-Psicose & $(+)$ & $(+)$ & $(-)$ & $(-)$ \\
\hline Pyruvic acid methyl ester & $(+)$ & $(-)$ & $(+)$ & $(+)$ \\
\hline L-Lactic acid & $(+)$ & $(+)$ & $(-)$ & $(+)$ \\
\hline Succinic acid monomethyl ester & $(-)$ & $(+)$ & $(+)$ & $(-)$ \\
\hline Propionic acid & $(-)$ & $(+)$ & $(-)$ & $(+)$ \\
\hline L-Alaninamide & $(-)$ & $(-)$ & $(+)$ & $(+)$ \\
\hline L-Alanyl glycine & $(-)$ & $(-)$ & $(+)$ & $(-)$ \\
\hline Inosine & $(+)$ & $(-)$ & $(+)$ & $(+)$ \\
\hline \multicolumn{5}{|l|}{ API ZYM results: } \\
\hline Alkaline phosphatase & (w) & + & $(+)$ & $(+)$ \\
\hline Lipase (C14) & (w) & + & $(-)$ & $(-)$ \\
\hline Leucine arylamidase & $(+)$ & - & $(+)$ & $(+)$ \\
\hline Valine arylamidase & $(\mathrm{w})$ & - & - & $\mathrm{V}$ \\
\hline Trypsin & $(-)$ & - & - & $\mathrm{w}$ \\
\hline$\alpha$-Chymotrypsin & $(-)$ & - & $(-)$ & $(-)$ \\
\hline Acid phosphatase & $(\mathrm{w})$ & + & + & $\mathrm{V}$ \\
\hline Naphthol-AS-BI-phosphohydrolase & $(w)$ & $\mathrm{w}$ & + & $\mathrm{v}$ \\
\hline$\beta$-Galactosidase & $(-)$ & - & $(-)$ & $(-)$ \\
\hline$\alpha$-Glucosidase & $(-)$ & + & + & $\mathrm{v}$ \\
\hline$\beta$-Glucosidase & $(-)$ & - & + & - \\
\hline Source of isolation & $\begin{array}{l}\text { Water flea Daphnia } \\
\text { cucullata }\end{array}$ & Alkaline soil & Alkaline soil & Soil \\
\hline DNA G + C content $(\mathrm{mol} \%)$ & 69.9 & $72.4-73.6$ & 70.6 & 69 \\
\hline
\end{tabular}




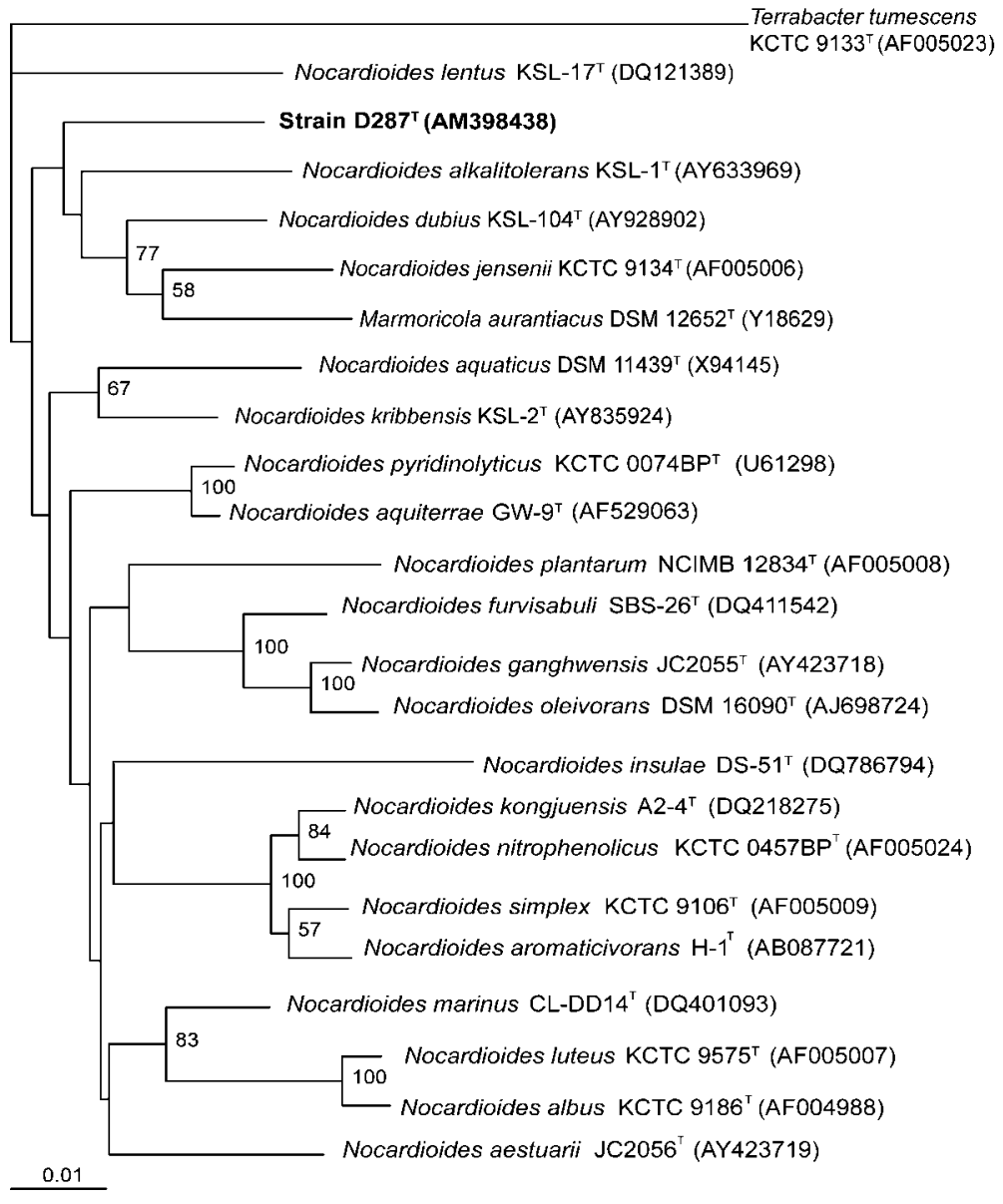

Fig. 1. 16S rRNA gene sequence neighbourjoining tree (Saitou \& Nei, 1987) showing the phylogenetic position of strain $\mathrm{D} 287^{\top}$ among members of the genera Nocardioides and Marmoricola. Bootstrap values ( $>50 \%)$ based on 1000 resamplings (Felsenstein, 1985) are indicated at nodes. Terrabacter tumescens KCTC $9133^{\top}$ served as the root for the tree. Bar, 1 nucleotide substitution per 100 nucleotides.
(Urzì et al., 2000). The $\mathrm{G}+\mathrm{C}$ value of the genomic DNA of strain $\mathrm{D} 287^{\mathrm{T}}$ was $69.9 \mathrm{~mol} \%$. The chemotaxonomic characteristics of strain $\mathrm{D} 287^{\mathrm{T}}$ are in accordance with its affiliation to the genus Nocardioides (Yoon \& Park, 2006).

Strain $\mathrm{D} 287^{\mathrm{T}}$ showed $16 \mathrm{~S}$ rRNA gene sequence similarity values below $97 \%$ to the type strains of all recognized species of the genus Nocardioides, the value generally accepted for the delineation of separate genomic species (Stackebrandt \& Goebel, 1994; Stackebrandt \& Ebers, 2006). It could additionally be differentiated from its phylogenetically nearest neighbours on the basis of several phenotypic characteristics (Table 1). It is therefore concluded that strain $\mathrm{D} 287^{\mathrm{T}}$ represents a novel species of the genus Nocardioides, for which the name Nocardioides daphniae sp. nov. is proposed.

\section{Description of Nocardioides daphniae sp. nov.}

Nocardioides daphniae (daph'ni.ae. N.L. gen. n. daphniae pertaining to the water flea genus Daphnia, as the type strain was isolated from Daphnia cucullata).

Gram-positive, aerobic, oxidase-negative, catalase-positive bacterium. Cells are non-motile, short rods or coccoids $(0.8-1.0 \times 1.2-2.2 \mu \mathrm{m})$. Colonies on King B agar medium are circular, convex, smooth, glistening and of yellowish colour. Spores and mycelia are not formed. The temperature range for growth is $4-38{ }^{\circ} \mathrm{C}$, with optimum growth at $28{ }^{\circ} \mathrm{C}$. The $\mathrm{pH}$ range for growth is $\mathrm{pH} 5.5-10.5$, with optimum growth between $\mathrm{pH} 7$ and 9. Growth occurs in the presence of $0-5 \% \mathrm{NaCl}$. Good growth occurs on King $\mathrm{B}$ and nutrient agar. $\mathrm{H}_{2} \mathrm{~S}$ and indole are not produced. Negative for the Voges-Proskauer and $\alpha$-glucosidase reactions. Acid is not produced from glucose. Haemolysin is not detected. Positive for production of chitinase. Weakly positive for caseinase. D-Fructose, $\alpha-D-$ glucose, D-mannose, trehalose, D-ribose, methyl $\beta$-Dglucoside, palatinose, psicose, sorbitol, stachyose, acetic acid, $\beta$-hydroxybutyric acid, $\gamma$-hydroxybutyric acid, $\alpha$-ketovaleric acid, L-lactic acid, D-malic acid, methylpyruvate, glycyl L-glutamic acid, pyruvic acid, 2,3-butanediol, adenosine, 2-deoxyadenosine, inosine, thymidine, uridine, adenosine $5^{\prime}$-monophosphate and uridine $5^{\prime}$ monophosphate are utilized as sole carbon source. $\alpha$ Cyclodextrin, $\beta$-cyclodextrin, dextrin, glycogen, inulin, mannan, Tweens 40 and $80, N$-acetylglucosamine, Larabinose, arabitol, arbutin, D-cellobiose, D-galactose, myoinositol, maltose, D-melezitose, D-melibiose, D-mannitol, Draffinose, L-rhamnose, sucrose, D-xylose, L-pyroglutamic acid, glycerol, D-galacturonic acid, gentiobiose, D-gluconic acid, lactulose, maltotriose, methyl $\alpha$-D-galactoside, methyl $\beta$-D-galactoside, methyl $\alpha$-D-mannoside, salicin, 
sedoheptulosan, tagatose, xylitol, $\alpha$-hydroxybutyric acid, $p$ hydroxyphenylacetic acid, lactamide, D-lactic acid methyl ester, methyl $\alpha$-D-glucoside, $\alpha$-D-lactose, L-malic acid, monomethyl succinate, succinamic acid, succinic acid, $\mathrm{N}$ acetyl-L-glutamic acid, alaninamide, D-alanine, L-alanine, L-alanyl glycine, L-asparagine, L-serine, putrescine, $\mathrm{N}$-acetylD-mannosamine, amygdalin, fucose, 3-methyl glucose, turanose, $\alpha$-ketoglutaric acid, propionic acid, L-glutamic acid, thymidine 5 '-monophosphate, DL- $\alpha$-glycerol phosphate, D-glucose 6-phosphate, D-fructose 6-phosphate, and glucose 1-phosphate are not utilized. The diagnostic diamino acid of the peptidoglycan is LL-2,6 diaminopimelic acid. The major menaquinone is $\mathrm{MK}-8\left(\mathrm{H}_{4}\right)$. Phosphatidylglycerol and diphosphatidylglycerol occur as polar lipids. The predominant cellular fatty acid is iso- $\mathrm{C}_{16: 0}$. The DNA G + C content is $69.9 \mathrm{~mol} \%$. Other phenotypic characteristics are given in Table 1.

The type strain, D $287^{\mathrm{T}}\left(=\mathrm{DSM} 18664^{\mathrm{T}}=\mathrm{CCM} 7403^{\mathrm{T}}\right)$, was isolated from the water flea Daphnia cucullata originating from Lake Balaton in Hungary.

\section{References}

Altschul, S. F., Madden, T. L., Schäffel, A. A., Zhang, Z., Miller, W. \& Lipmann, D. J. (1997). Gapped BLAST and PSI-BLAST: a new generation of protein database search programs. Nucleic Acids Res 25, 3389-3402.

Cashion, P., Holder-Franklin, M. A., McCully, J. \& Franklin, M. (1977). A rapid method for base ratio determination of bacterial DNA. Anal Biochem 81, 461-466.

Choi, D. H., Kim, H. M., Noh, J.-H. \& Cho, B. C. (2007). Nocardioides marinus sp. nov. Int J Syst Evol Microbiol 57, 775-779.

Claus, M. (1992). A standardised Gram staining procedure. World J Microbiol Biotechnol 8, 451-452.

Collins, M. D., Pirouz, T., Goodfellow, M. \& Minnikin, D. E. (1977). Distribution of menaquinones in actinomycetes and corynebacteria. $J$ Gen Microbiol 100, 221-230.

Collins, M. D., Dorsch, M. \& Stackebrandt, E. (1989). Transfer of Pimelobacter tumescens to Terrabacter gen. nov. as Terrabacter tumescens comb. nov. and of Pimelobacter jensenii to Nocardioides as Nocardioides jensenii comb. nov. Int J Syst Bacteriol 39, 1-6.

Collins, M. D., Cockcroft, S. \& Wallbanks, S. (1994). Phylogenetic analysis of a new LL-diaminopimelic acid-containing coryneform bacterium from herbage, Nocardioides plantarum sp. nov. Int J Syst Bacteriol 44, 523-526.

Cowan, S. T. \& Steel, K. J. (1974). Manual for the Identification of Medical Bacteria. London: Cambridge University Press.

Elek, S. D. \& Levy, E. (1954). The nature of discrepancies between haemolysins in culture filtrates and plate haemolysin patterns of staphylococci. J Path Bact 68, 31-33.

Felsenstein, J. (1981). Evolutionary trees from DNA sequences: a maximum likelihood approach. J Mol Evol 17, 368-376.

Felsenstein, J. (1985). Confidence limits on phylogenies: an approach using the bootstrap. Evolution 39, 783-789.

Groth, I., Schumann, P., Weiss, N., Martin, K. \& Rainey, F. A. (1996). Agrococcus jenensis gen. nov., sp. nov., a new genus of actinomycetes with diaminobutyric acid in the cell wall. Int J Syst Bacteriol 46, 234-239.

Groth, I., Schumann, P., Rainey, F. A., Martin, K., Schietze, B. \& Augsten, K. (1997). Demetria terragena gen. nov., sp. nov., a new genus of actinomycetes isolated from compost soil. Int J Syst Bacteriol 47, 1129-1133.

G.-Tóth, L. (2000). Nutrition of planktonic crustacea and their role in the elimination of phytoplankton in Lake Balaton. $\mathrm{PhD}$ dissertation, Tihany (in Hungarian).

Hall, T. A. (1999). BioEdit: a user-friendly biological sequence alignment editor and analysis program for Windows 95/98/NT. Nucleic Acids Symp Ser 41, 95-98.

Hasegawa, T., Takizawa, M. \& Tanida, S. (1983). A rapid analysis for chemical grouping of aerobic actinomycetes. J Gen Appl Microbiol 29, 1319-1322.

Holding, A. J. \& Collee, J. G. (1971). Routine biochemical tests. Methods Microbiol 6A, 1-5.

Homonnay, Z. G., Kéki, Zs., G.-Tóth, L. \& Tóth, E. (2006). Cultured bacterial communities of planktonic crustaceans (Daphnia cucullata, Eudiaptomus gracilis) of Lake Balaton (Hungary). Hidrol Közl 86, 5153 (in Hungarian).

Hugh, R. \& Leifson, E. (1953). The taxonomic significance of fermentative versus oxidative metabolism of carbohydrates by gram negative bacteria. J Bacteriol 66, 24-26.

Kimura, M. (1980). A simple method for estimating evolutionary rates of base substitutions through comparative studies of nucleotide sequences. J Mol Evol 16, 111-120.

King, E. O., Ward, M. K. \& Rainey, D. E. (1954). Two simple media for the demonstration of pyocyanin and fluorescein. J Lab Clin Med 44, 301-302.

Kubota, M., Kawahara, K., Sekiya, K., Uchida, T., Hattori, Y., Futamata, H. \& Hiraishi, A. (2005). Nocardioides aromaticivorans sp. nov., a dibenzofuran-degrading bacterium isolated from dioxinpolluted environments. Syst Appl Microbiol 28, 165-174.

Lawson, P. A., Collins, M. D., Schumann, P., Tindall, B. J., Hirsch, P. \& Labrenz, M. (2000). New LL-diaminopimelic acid-containing actinomycetes from hypersaline, heliothermal and meromictic Antarctic Ekho Lake: Nocardioides aquaticus sp. nov. and Friedmanniella [correction of Friedmannielly] lacustris sp. nov. Syst Appl Microbiol 23, 219-229.

Lee, S. D. (2007). Nocardioides furvisabuli sp. nov., isolated from black sand. Int J Syst Evol Microbiol 57, 35-39.

Mesbah, M., Premachandran, U. \& Whitman, W. B. (1989). Precise measurement of the $\mathrm{G}+\mathrm{C}$ content of deoxyribonucleic acid by highperformance liquid chromatography. Int J Syst Bacteriol 39, 159-167.

Minnikin, D. E., Collins, M. D. \& Goodfellow, M. (1979). Fatty acid and polar lipid composition in the classification of Cellulomonas, Oerskovia and related taxa. J Appl Bacteriol 47, 87-95.

O’Donnell, A. G., Goodfellow, M. \& Minnikin, D. E. (1982). Lipids in the classification of Nocardioides: reclassification of Arthrobacter simplex (Jensen) located in the genus Nocardioides (Prauser) emend. O'Donnell et al. as Nocardioides simplex comb. nov. Arch Microbiol 133, 323-329.

Prauser, H. (1976). Nocardioides, a new genus of the order Actinomycetales. Int J Syst Bacteriol 26, 58-65.

Prauser, H. (1984). Nocardioides luteus spec. nov. Z Allg Mikrobiol 24, 647-648.

Rainey, F. A., Rainey, W. N., Kroppenstedt, R. M. \& Stackebrandt, E. (1996). The genus Nocardiopsis represents a phylogenetically coherent taxon and a distinct actinomycete lineage: proposal of Nocardiopsaceae fam. nov. Int J Syst Bacteriol 46, 1088-1092.

Saitou, N. \& Nei, M. (1987). The neighbor-joining method: a new method for reconstructing phylogenetic trees. Mol Biol Evol 4, 406-425. 
Schippers, A., Schumann, P. \& Sproer, C. (2005). Nocardioides oleivorans sp. nov., a novel crude-oil-degrading bacterium. Int J Syst Evol Microbiol 55, 1501-1504.

Smibert, R. M. \& Krieg, N. R. (1994). Phenotypic characterization. In Methods for General and Molecular Bacteriology, pp. 607-654. Edited by P. Gerhardt, R. G. E. Murray, W. A. Wood \& N. R. Krieg. Washington, DC: American Society for Microbiology.

Stackebrandt, E. \& Ebers, J. (2006). Taxonomic parameters revisited: tarnished gold standards. Microbiology Today 33, 152-155.

Stackebrandt, E. \& Goebel, B. M. (1994). Taxonomic note: a place for DNA-DNA reassociation and $16 \mathrm{~S}$ rRNA sequence analysis in the present species definition in bacteriology. Int J Syst Bacteriol 44, 846-849.

Stead, D. E., Sellwood, J. E., Wilson, J. \& Viney, I. (1992). Evaluation of a commercial microbial identification system based on fatty acid profiles for rapid, accurate identification of plant pathogenic bacteria. J Appl Bacteriol 72, 315-321.

Suzuki, K. \& Komagata, K. (1983). Pimelobacter gen. nov., a new genus of coryneform bacteria with LL-diaminopimelic acid in the cell wall. J Gen Appl Microbiol 29, 59-71.

Tamaoka, J. \& Komagata, K. (1984). Determination of DNA base composition by reversed-phase high-performance liquid chromatography. FEMS Microbiol Lett 25, 125-128.

Tarrand, J. J. \& Gröschel, D. H. M. (1982). Rapid, modified oxidase test for oxidase-variable bacterial isolates. J Clin Microbiol 16, 772-774.

Thompson, J. D., Gibson, T. J., Plewniak, F., Jeanmougin, F. \& Higgins, D. G. (1997). The CLUSTAL_X windows interface: flexible strategies for multiple sequence alignment aided by quality analysis tools. Nucleic Acids Res 25, 4876-4882.

Urzì, C., Salamone, P., Schumann, P. \& Stackebrandt, E. (2000). Marmoricola aurantiacus gen. nov., sp. nov., a coccoid member of the family Nocardioidaceae isolated from a marble statue. Int J Syst Evol Microbiol 50, 529-536.

Yamada, K. \& Komagata, K. (1972). Taxonomic studies on coryneform bacteria. IV. Morphological, cultural, biochemical, and physiological characteristics. J Gen Appl Microbiol 18, 399-416.
Yi, H. \& Chun, J. (2004a). Nocardioides ganghwensis sp. nov., isolated from tidal flat sediment. Int J Syst Evol Microbiol 54, 1295-1299.

Yi, H. \& Chun, J. (2004b). Nocardioides aestuarii sp. nov., isolated from tidal flat sediment. Int J Syst Evol Microbiol 54, 2151-2154.

Yoon, J. H. \& Park, Y. H. (2006). The genus Nocardioides. In The Prokaryotes, vol. 3, pp. 1099-1113. Edited by M. Dworkin, S. Falkow, E. Rosenberg, K. H. Schleifer \& E. Stackebrandt. New York: Springer.

Yoon, J.-H., Rhee, S., Lee, J., Park, Y. \& Lee, S. (1997). Nocardioides pyridinolyticus sp. nov., a pyridine-degrading bacterium isolated from the oxic zone of an oil shale column. Int J Syst Bacteriol 47, 933-938.

Yoon, J.-H., Cho, Y., Lee, S., Suzuki, K., Nakase, T. \& Park, Y. (1999). Nocardioides nitrophenolicus sp. nov., a p-nitrophenol-degrading bacterium. Int J Syst Bacteriol 49, 675-680.

Yoon, J.-H., Kim, I.-G., Kang, K. H., Oh, T.-K. \& Park, Y.-H. (2004). Nocardioides aquiterrae sp. nov., isolated from groundwater in Korea. Int J Syst Evol Microbiol 54, 71-75.

Yoon, J.-H., Kim, I.-G., Lee, M.-H., Lee, C.-H. \& Oh, T.-K. (2005a). Nocardioides alkalitolerans sp. nov., isolated from an alkaline serpentinite soil in Korea. Int J Syst Evol Microbiol 55, 809-814.

Yoon, J.-H., Kim, I.-G., Lee, M.-H. \& Oh, T.-K. (2005b). Nocardioides kribbensis sp. nov., isolated from an alkaline soil. Int J Syst Evol Microbiol 55, 1611-1614.

Yoon, J.-H., Lee, C.-H. \& Oh, T.-K. (2005c). Nocardioides dubius sp. nov., isolated from an alkaline soil. Int J Syst Evol Microbiol 55, 2209-2212.

Yoon, J.-H., Lee, C.-H. \& Oh, T.-K. (2006a). Nocardioides lentus sp. nov., isolated from an alkaline soil. Int J Syst Evol Microbiol 56, 271-275.

Yoon, J.-H., Lee, J.-K., Jung, S.-Y., Kim, J.-A., Kim, H.-K. \& Oh, T.-K. (2006b). Nocardioides kongjuensis sp. nov., an $N$-acylhomoserine lactone-degrading bacterium. Int J Syst Evol Microbiol 56, 1783-1787.

Yoon, J.-H., Kang, S.-J., Lee, C.-H. \& Oh, T.-K. (2007). Nocardioides insulae sp. nov., isolated from soil. Int J Syst Evol Microbiol 57, 136-140. 